\title{
APLASTIC ANAEMIA AND SEVERE HEPATIC ZONAL NECROSIS AFTER ANTI-SYPHILITIC TREATMENT*
}

\author{
BY \\ A. W. B. EDMUNDS \\ Memorial Hospital, Darlington
}

The following case presented two complications of anti-syphilitic therapy, aplastic anaemia which is rare, and hepatitis, which is relatively common. In this instance the hepatitis progressed to severe zonal necrosis which caused death from hepatic failure.

\section{Case Report}

A married man aged 53 reported to the venereal diseases clinic in March, 1949, when he was found to have syphilis with an early secondary rash. A penile sore was present, and the Wassermann reaction was strongly positive. Treatment with Stabilarsan and bismuth was begun, and he received a total of $16.2 \mathrm{~g}$. of the former, and $5.7 \mathrm{~g}$. of the latter (a normal course) between March, 1949, and January, 1950, when he was given his last injection. About December, 1949, he had begun to complain of lassitude and anorexia, and in January, 1950, he became increasingly pale and dyspnoeic on exertion. On March 18, 1950, he was admitted to Darlington Memorial Hospital in an extremely pale and semi-comatose condition with temperature $98.0^{\circ} \mathrm{F}$., pulse 120 , and respiration 30 . No icterus was present. There was a good deal of dental caries and pyorrhoea together with a severe stomatitis and gingivitis. In addition, a bluish-grey line was visible near the gum margins, and there were small patches of similar pigmentation on the mucous membrane of the cheeks. There was a moderate degree of sacral but no ankle oedema, and the neck veins were distended. No cutaneous or retinal haemorrhages were visible, and there was no enlargement of superficial lymph nodes. The liver could be felt, firm and smooth, with a regular edge, $4 \mathrm{~cm}$. below the costal margin, but the spleen was not palpable. No cardiac enlargement could be made out clinically ; there was a soft apical systolic murmur, and many crepitations were heard at the lung bases. The blood pressure was $110 / 80$. The capillary resistance test was positive. The urine contained a trace of albumin.

On admission, haemoglobin was 16 per cent. $(14 \mathrm{~g} .=$ 100 per cent.); red blood cells 730,000 per c.mm., white blood cells 7250 per c.mm. (polymorphonuclear

\footnotetext{
* Received for publication October 61953.
}

leucocytes 74 per cent., lymphocytes 25 per cent., monocytes 1 per cent.), platelets 208,000 per c.mm.

A stained film showed the red cells to be normal in size, shape, and staining. No primitive cells were seen.

Treatment with penicillin and iron was commenced, and packed cells from three pints of blood were given slowly during the first 2 days, the haemoglobin rising to 48 per cent. on March 21, 1950. Intramuscular injections of B.A.L. (2,3 dimercaptopropanol) were started on March 19, 1950 ( $2 \mathrm{ml}$. intramuscularly four times on the first day, twice daily for 4 days, and then daily for 2 days). The general condition of the patient improved rapidly, although he was for some days very confused and required sedation with paraldehyde. By March 31, the oral sepsis had largely disappeared, though the pigmentation persisted. After the first day there was no albuminuria, and the specific gravity of the urine rose on occasions to 1,020 . Sternal puncture was performed on March 21, the count on films made from the aspirated marrow being as in Table I. Radiography on March 27, 1950 , showed generalized enlargement of the heart and

TABLE I

DIFFERENTIAL COUNT ON SMEARS FROM STERNAL MARROW

(March 21, 1950)

\begin{tabular}{|c|c|c|c|c|c|c|}
\hline \multicolumn{6}{|c|}{ Type of Cell } & \multirow{2}{*}{ Percent. of Total } \\
\hline Myeloblasts & .. & .. & .. & . & $\cdots$ & \\
\hline Promyelocytes & & . & . & . & $\ldots$ & 0.4 \\
\hline Neutrophil myelo & ocytes & $\ldots$ & $\ldots$ & $\ldots$ & - & $6 \cdot 0$ \\
\hline Eosinophil myelo & pcytes & $\ldots$ & . & $\ldots$ & .. & $2 \cdot 6$ \\
\hline Basophil myelocy & $y$ tes & . & . & . & . & - \\
\hline Metamyelocytes & & . & . & . & . & $5 \cdot 8$ \\
\hline Polymorphonucle & ear leu & cocytes & . & . & . & $52 \cdot 8$ \\
\hline Eosinophil leucoc & cytes & . & . & . & $\cdots$ & $0 \cdot 8$ \\
\hline Basophil leucocy & tes & . & . & . & . & $\overline{1}$ \\
\hline Lymphocytes & . & $\cdots$ & $\cdots$ & . & . & $24 \cdot 0$ \\
\hline Monocytes & $\ldots$ & . & $\cdots$ & . & . & $2 \cdot 4$ \\
\hline Proery throblasts & . & . & . & . & . & $1 \cdot 0$ \\
\hline Normoblasts & . & . & $\cdots$ & . & . & $3 \cdot 6$ \\
\hline Mitosis $\quad \ldots$ & . & . & . & . & . & $0 \cdot 2$ \\
\hline Haemocy toblasts & & . & . & . & . & $0 \cdot 2$ \\
\hline
\end{tabular}

There is a very great predominance of the white cell series over the red cells. The latter are depressed to a very marked degree, which confirms the original findings in the peripheral blood. It appears that there has been some selective damage to the bone marrow picking out the red cell series to the exclusion of the rest. 
TABLE II

SUMMARY OF PERIPHERAL BLOOD FINDINGS

\begin{tabular}{|c|c|c|c|c|c|c|c|c|c|}
\hline Date & $\begin{array}{l}\text { Haemoglobin } \\
\text { (Per cent.) }\end{array}$ & $\begin{array}{c}\text { Red Blood } \\
\text { Corpuscles } \\
\text { (millions } \\
\text { per c.mm.) }\end{array}$ & $\begin{array}{c}\text { Reticulocytes } \\
\text { (Per cent.) }\end{array}$ & $\begin{array}{l}\text { White Blood } \\
\text { Corpuscles } \\
\text { (per c.mm.) }\end{array}$ & $\begin{array}{l}\text { Polymorphs } \\
\text { (Per cent.) }\end{array}$ & $\begin{array}{c}\text { Lymphocytes } \\
\text { (Per cent.) }\end{array}$ & $\begin{array}{l}\text { Monocytes } \\
\text { (Per cent.) }\end{array}$ & $\begin{array}{c}\text { Eosinophils } \\
\text { (Per cent.) }\end{array}$ & Platelets \\
\hline 17.3 .50 & 16 & 0.73 & 1.6 & 7,250 & 74 & 25 & 1 & - & 208,000 \\
\hline 11.4 .50 & 32 & $1 \cdot 7$ & - & 5,800 & 52 & 36 & 11 & 1 & 176,000 \\
\hline 4.5 .50 & 65 & $2 \cdot 6$ & - & 4,300 & 66 & 33 & - & 1 & 178,000 \\
\hline 13.6 .50 & 34 & 1.6 & - & 1,400 & 48 & 52 & - & - & "Deficient" \\
\hline 7.7 .50 & 59 & 2.6 & 0.3 & 1,900 & 49 & 48 & 3 & - & 122,000 \\
\hline 28.8 .50 & 48 & $2 \cdot 3$ & Less than 1 & 2,500 & 59 & 35 & 4 & 2 & 100,000 \\
\hline
\end{tabular}

no abnormality in the lung fields. Repeated transfusions of packed cells were given, but with only temporary improvement in the red cell count and haemoglobin level, although, as shown in Table II, the leucocyte and platelet counts remained fairly normal until in June they too began to fall. The capillary resistance test remained positive throughout, and on April 20, 1950, the first spontaneous haemorrhage appeared in the form of an ecchymosis in one eyelid.

The picture became more complicated when on April 28, 1950, the patient was noticed to be slightly jaundiced (serum bilirubin had been $0.3 \mathrm{mg}$. $/ 100 \mathrm{ml}$. on April 11, 1950). An obstructive element was shown by the presence of bile pigment and excess urobilinogen in the urine. The liver edge was still palpable $4.0 \mathrm{~cm}$. below the costal margin.

Liver function tests (May 4, 1950) were as follows :

$$
\begin{array}{llr}
\text { Serum bilirubin } \ldots & \ldots & 5.4 \mathrm{mg} . / 100 \mathrm{ml} \text {. } \\
\text { Alkaline phosphatase } & \ldots & 31.5 \mathrm{units}
\end{array}
$$$$
\text { Thymol turbidity .. } \quad . .6 \quad 6 \text { units }
$$

Serum proteins : Total $5.5 \mathrm{~g} . / 100 \mathrm{ml}$. (albumin $2 \cdot 8$ g., globulin $2 \cdot 7$ g.).

It was thought that the patient probably had homologous serum jaundice.

The jaundice decreased during the next 2 months, and liver function tests on July 25,1950 , showed a slight improvement. Marrow puncture was repeated on August 4, the aspirated material now presenting a picture identical with that of the peripheral blood, suggesting that the marrow had become aplastic.

In spite of the unfavourable prognosis, it was decided to allow the patient to go home for a time and he was discharged on August 11, 1950, the haemoglobin level having been brought by transfusion to 80 per cent. The Kahn test on his blood was then negative. The haemoglobin fell rapidly however, and at the same time the jaundice deepened again, and ascites and dependent oedema appeared. The liver enlargement remained as before. On August 29, 1950, he was re-admitted for further transfusions. Despite restoration and maintenance of his haemoglobin level, and administration of adequate amino-acids he became drowsy due to terminal hepatic failure. Liver function tests on September 4, 1950 , showed a deterioration in keeping with his clinical condition.

$\begin{array}{lll}\text { Serum bilirubin } \ldots & . . & 6.4 \mathrm{mg} . / 100 \mathrm{ml} . \\ \text { Alkaline phosphatase } & . . & 22 \mathrm{units} \\ \text { Thymol turbidity } . . & . . & 4.5 \text { units }\end{array}$

Serum proteins : Total $4.4 \mathrm{~g} . / 100 \mathrm{ml}$. (albumin $2 \cdot 8 \mathrm{~g}$., globulin $1.6 \mathrm{~g}$.).

Transfusions were then stopped as the prognosis was hopeless, a total of 34 pints, chiefly as packed cells, having been given. He died in coma September 23, 1950. Marrow puncture a few days before death again yielded material identical with the peripheral blood.

\section{Necropsy Findings \\ (September 25, 1950)}

The body was that of a wasted, pale, yellow man with a distended abdomen and grossly oedematous legs. The abdominal distension was due to approximately eight pints of orange-yellow fluid. The liver was only slightly enlarged with a finely granular capsular surface whilst the cut surface was an orange-brown with pale cream coloured speckling throughout and completely devoid of any normal pattern. The gall bladder was distended and the common bile duct was occluded by oedema. The spleen was slightly enlarged. The lungs were congested and grossly oedematous. The marrow throughout the femur was yellow and fatty, but there was a small amount of red marrow in the sternum.

Microscopically, the liver showed almost complete necrosis of the parenchymal cells, only one or two cells surviving at the periphery of each lobule. There was an increase in fibrous tissue around the portal systems and these were linked with one another by fibrous bands running between the liver lobules.

\section{Discussion}

Blood dyscrasia due to organic arsenical therapy is rare. Stephenson and Chambers (1940) reported only 24 cases resulting from 1,244,537 injections in the U.S. Navy between 1925 and 1938. The dys- 
crasias were classified by McCarthy and Wilson (1932) into three groups :

(1) Thrombocytopenic, with haemorrhages, developing immediately or within a few days after an injection, usually early in treatment and with rapid recovery. A few of the cases showed granulocytopenia as well, also with recovery.

(2) Granulocytopenic, appearing, on the average, after five injections, with four deaths in their series of twelve cases. (In six similar cases described by Ferguson (1944) there were three deaths.)

(3) " Aplastic," occuring usually after a long series of injections had been given, and showing a mortality rate of 83 per cent. in 34 cases.

McCarthy and Wilson considered their first group to be due to the development of hypersensitivity to the arsenical drug.

Cases in the second and third group fall into one or other of the types of " refractory anaemia ", as classified on the marrow picture by Bomforda nd Rhoads (1941) :

(1) Those with partly mature cellular marrow,

(2) those with hypo-cellular marrow (aplastic anaemia in the strict sense),

(3) those with immature cellular marrow, consisting mainly of erythroblasts, and showing granulocytopenia in the peripheral blood.

In the case under review, both the peripheral blood and the marrow picture indicated at the outset that, as far as could be judged, the brunt of the damage was borne by the red cell series exclusively. There were, however, a few reticulocytes in the peripheral blood and some red cell precursors in the marrow, so that this case, in its early stages, cannot be classed with the very rare, pure red cell, aplasias described by various writers (Lescher and Hubble, 1932 ; Mills, 1931 ; Kark, 1937 ; Macfarlane and Currie, 1943 ; Vaughan, 1942 ; Begemann, 1947) in which both are completely absent, and which appear to have occurred only in idiopathic cases. Leucopenia did not become evident until over 2 months after this patient was admitted to hospital, and thrombocytopenia was never severe. By the classification of Bomford and Rhoads (1941), this case in the early stages would fall into their first group (refractory anaemia with partly mature cellular marrow). It differs from the usual, however, in that they found that in all but a few cases the proportion of erythropoietic to leucopoietic cells was above normal, and no other case of which we have read (Schrire, 1945; Merskey, 1946; Hart and Humble, 1949; Partington and Rogers, 1951) has shown this selective damage to the erythron. Later, of course, the marrow showed aplasia of all elements, as in their second group. This trend in the marrow picture was prognostic of a fatal termination, but hepatic failure hastened death.

It could not be said that there was any evidence of benefit to the haemopoietic system from the B.A.L., though improvement in the stomatitis (presumably due to bismuth) was dramatic. This lack of response was in keeping with the findings of Eagle (1946), who reported no effect from 2, 3 dimercaptopropanol in cases of aplastic anaemia due to organic arsenic, though there was evidence of benefit in patients with arsenical agranulocytosis.*

It is possible, of course, that, in the case reported here, B.A.L. postponed the development of agranulocytosis (and perhaps of thrombocytopenia). If, as suggested by McCarthy and Wilson (1932), it is the benzene ring of arsphenamine rather than the arsenic which causes the marrow aplasia, this failure of B.A.L. is probably to be expected. They could find only one reported case in which inorganic arsenic caused a blood dyscrasia (granulocytopenia). One of the rare recoveries from such aplastic anaemia, however, was reported by Partington and Rogers (1951) who used B.A.L.

Bismuth may possibly have been a contributory cause of the marrow depression, but reports of blood dyscrasias after its use seem to be few. (Dassen and Rey, purpura, 1930; Sézary and Boucher, agranulocytosis, 1931 ; Dowds, agranulocytosis, 1937.)

The hepatic lesion was a very severe zonal necrosis amounting almost to a massive necrosis. Though it was considered to be due to the virus of serum hepatitis and to have taken this severe course perhaps because of the anaemia, organic arsenic cannot be exonerated completely as it has been shown to cause zonal necrosis in animals on a diet deficient in protein (Himsworth, 1950). The same authority has indicated how zonal necrosis may lead to massive necrosis in the presence of nutritional deficiency.

\section{Summary}

A case is reported in which organic arsenical therapy was followed by both aplastic anaemia and a severe hepatitis, probably due to the virus of homologous serum jaundice.

I wish to thank Dr. G. D. Owen for his helpful suggestions and permission to publish this case, Dr. Donald Payne for reports on bone marrow and necropsy findings, and Messrs. Shaw, Crallan, and Matthews, of Darlington

* The American Council of Pharmacy and Chemistry (1946) found that in ten out of eleven cases of arsenical agranulocytosis, the administration of B.A.L. was followed by an increase in the polymorphonuclear count. 
Memorial Hospital laboratory staff, for the biochemical and haematological work.

\section{REFERENCES}

American Council on Pharmacy and Chemistry (1946). J. Amer. med. Ass., 131, 824.

Begemann, H. (1947). Klin. Wschr., 24, 850.

Bomford, R. R., and Rhoads, C. P. (1941). Quart. J. Med., 10, 175.

Dassen, R., and Rey, J. C. (1930). Sem. méd., 37 (2), 1152.

Dowds, J. H. (1937). Brit. med. J., 2, 620.

Eagle, H. (1946). J. vener. Dis. Inform., 27, 114.

Ferguson, J. W. (1944). Lancet, 1, 334.

Hart, F. D., and Humble, J. G. (1949). Brit. med. J., 1, 1120
Himsworth, H. P. (1950). " Lectures on the Liver and its Diseases." 2nd ed., p. 113. Blackwell, Oxford.

Kark, R. M. (1937). Guy's Hosp. Rep., 87, 343.

Lescher, F. G., and Hubble, D. (1932). Quart. J. Med., 1, 425.

Merskey, C. (1946). Clin. Proc., 5, 256.

McCarthy, F. P., and Wilson, R. (1932). J. Amer, med. Ass., 99, 1557.

Macfarlane, J. W., and Currie, J. P. (1943). Edinb. med. J. 50, 171.

Mills, E. S. (1931). Amer. J. med. Sci., 181, 521.

Partington, C. N., and Rogers, W. (1951). Brit. med. J., 1, 1301.

Schrire, V. (1945). Clin. Proc., 4, 567.

Sézary, A., and Boucher, G. (1931). Bull. Soc. méd. Hôp. Paris, 47, 1795 .

Stephenson, C. S., and Chambers, W. M. (1940). Nav. med. Bull., Wash., 38, 126. Quoted by Ferguson (1944).

Vaughan, S. L. (1942). N.Y. St. J. Med., 42, 978. 